\title{
INTERNATIONAL HUMAN RIGHTS AND JUSTICE REFORMS IN UZBEKISTAN
}

\author{
Imamov Rustamjon \\ Doctor of Philosophy (PhD) in Law, Associate Professor of Andizhan State University, \\ Andizhan, Republic of Uzbekistan
}

Article DOI: https://doi.org/10.36713/epra4161

\begin{abstract}
In this article have been analyzed international human rights and justice reforms in Uzbekistan by the law literatures and sources. Besides, research illuminates that at the same time, from the very first period of independence, reforms in this area have been consistently implemented and liberalization of criminal law, specialization of the judicial system as well.
\end{abstract}

KEY WORDS: international human rights, justice reforms, Uzbekistan, freedom, international community, liberalization, criminal law, democracy, legislation.

\section{INTRODUCTION}

In the course of 29 years of development of the country, which aims to build a democratic legal state, reform of the judicial sphere has played an important role, and today it does not lose its relevance. At the same time, from the very first period of independence, reforms in this area have been consistently implemented. Liberalization of criminal law, specialization of the judicial system. At the same time, the legislation in this area is being brought in line with generally accepted and international standards to which the Republic of Uzbekistan has joined. Because, as a part of the international community, Uzbekistan is recognized by the humanity and aims to live up to the standards of living that all democratic nations seek, and to equip their people with the leading nations of the world. To this end, Uzbekistan is currently a member of more than 60 international treaties on the protection of human rights and freedoms and fulfills its obligations under these treaties.

\section{METHODS}

These include the Universal Declaration of Human Rights, adopted by UN General Assembly Resolution 217-A (III) of December 10, 1948, the International Covenant on Civil and Political Rights of 1966 and two additional declarations on economic, social and cultural rights. International Covenant,
Temporary Documents: International Convention on the Elimination of All Forms of Discrimination against Women, International Convention on the Elimination of All Forms of Racial Discrimination, Torture and Other Share, no human or degrading punishment Defendant and kanventsiya against the Convention on the Rights of the child [1] as well as armed conflicts aimed at the protection of the rights of conventions in Geneva and in addition to acts [2] and other documents. For this purpose great attention is paid to the improvement of national legislation and practice.

\section{RESULTS AND DISCUSSIONS}

In this regard, the Decree "On abolition of the death penalty as a type of punishment" and "On transfer to the courts of the right to issue arrest warrants" was issued in accordance with - abolition of the death penalty in our country from January to January, transfer of arrest warrant from prosecutor's office to judicial authority is not only Uzbekistan's democratic path, but also demonstrates that he is also fulfilling his international obligations arising from international instruments, and that he is interested in it.

Speaking about the judicial reforms in the country, the President of the Republic of Uzbekistan Sh.M. Mirziyoev said, "You know that in recent years, large-scale reforms are being implemented in 


\section{EPRA International Journal of Research and Development (IJRD)}

Volume: 5 | Issue: 3 | March 2020

our country to ensure the rule of law and improve the judicial system. These changes are aimed at ensuring human rights and freedoms, access to justice, and improving the work of law enforcement agencies". Also, our President Sh.M. Mirziyoev has shown that "Judgment must be in the mind of the judge - justice, in the language - only truth, and purity in the heart" [3].

The state's emphasis on the judiciary and the great emphasis on judicial reform in the country is primarily about the consistent implementation of a democratic state based on legal civil society. This is because, during the totalitarian period, there is a tendency for the functioning of the judiciary to manifest itself as a punitive body. The judiciary has failed to fully fulfill its role as a "Justice Scale" in the judiciary, unable to operate independently as a result of its activities under the rule of a political party and mainly by senior party officials. There have even been cases where people have been punished by nonviolent investigators. There are many examples from history. How many individuals, our compatriots, were victims of political repression as a result of poor justice during this period.

On December 8, 1992, based on our traditions, national history, and best international practices, our Constitution was adopted on September 30, 1991, consistent with the requirements of the Universal Declaration of Human Rights. In our constitution the authorities were brought to the level of the judiciary, and to the independent power, ie. to the judiciary, based on the principle of division. Article 106 of the Constitution of the Republic of Uzbekistan establishes that the judicial power in the Republic of Uzbekistan operates independently of the legislative and executive authorities of political parties, other political parties, and other public associations. Based on this, judicial reform in our country is still continuing. In recent years, several presidential decrees and laws of government decisions have been adopted to improve the courts.

In particular, the Decree of the President of the Republic of Uzbekistan Sh.Mirziyoev on July 13, 2018 "On measures to further improve the judicial system and increase confidence in the judiciary" was adopted. August 30, 1995 "On the Constitutional Court of the Republic of Uzbekistan", September 23, 1999 "On the establishment of the Military Court of the Republic of Uzbekistan"; In December this law was adopted in a new edition.

Especially since July 2018, Presidential Decree specialization of judges has played an important role in the process of judicial reform and in the history of our society. This has led to the timely and objective resolution of criminal and administrative, civil and economic cases, and the consistent implementation of the rule of law. Judicial authority is exempted from specific functions such as enforcement of court decisions. This was another finding of the essence of the principle of separation of powers between the authorities.

Simultaneously with the specialization of courts, criminal legislation is being reformed. The harsh and brutal punishment of the former Soviet system has been liberalized, taking into account social changes in society. One of the important steps in this area is the adoption of the Law "On Amendments and Additions to the Criminal, Criminal Procedure Codes and Administrative Code of the Republic of Uzbekistan in connection with the liberalization of criminal sanctions" of August 29, 2001. According to him, the classification of crimes has radically changed based on the principles of humanity. Measures to liberalize the penal system have also been of great social and political importance. As a result, about $75 \%$ of serious and very serious crimes were classified as less serious and less serious crimes [4, p.39]. In the criminal law, if the offender reimburses material damages, the court has extended incentives that do not allow him to be punished by imprisonment. In the penitentiary system, alternative types of punishment have been expanded. This also ensures that penalties for crimes are fair. Following the adoption of these amendments, the courts' sentence of imprisonment in 2006 has dropped by almost 20 percent compared to 2000 . The establishment of the institution of reconciliation also plays an important role in this regard.

As we reflect on the impact of judicial reform on the criminal situation in the country since the independence, the Russian lawyer V.V. Luneev's point is appropriate. In particular, he wrote "Crime XX century" world, Regional and Russian Trends provides the following data on the level of crime in Uzbekistan, namely: the crime rate decreased from $121.2 \%$ in 2002 to 106.2 in 2002 [5, p.241].

\section{CONCLUSION}

Considering the aforementioned cases, judicial and legal reforms that have taken place during the rule of law-building are achieving positive results. Protection of the rights and lawful interests of our citizens as reflected in international legal documents and the imposition of penalties for crimes, adherence to the principles of justice and humanism are one of the main tasks of a democratic, legal state and civil society.

\section{REFERENCES}
1. International Human Rights Chronicles: Collection / Uzbek. Editor-in-Chief Editor A. Saidov-Tashkent: Adolat, 2004.
2. International Humanitarian Law. Collection of Geneva Conventions. - Tashkent: Adolat, 2002.
3. Mirziyoev Sh.M. The Most Important Ways to Achieve Our Good Goals in Advancing the Rule 


\section{EPRA International Journal of Research and Development (IJRD)}

Volume: 5 | Issue: 3 | March 2020

- Peer Reviewed Journal

of Law and Justice. Tashkent, 2017

4. Odilkariev H. Reforms in the judicial sphere: achievements and problems // Proceedings of the scientific-practical conference on the formation of the activity of judicial and law enforcement agencies on the new grounds during the years of independence. -Tashkent: TSUL, 2007. -p.39

5. For more details, see Luneev V.V. Crime XX century. Factor: Mobility, Regional and Russian Trends. -Moscow: Voltere Kluver, 2005. -p.241. 